GLOBAL JOURNAL OF PURE AND APPLIED SCIENCES VOL. 18, NO. 3\&4, 2012: 125-133 COPYRIGHT@ BACHUDO SCIENCE CO. LTD PRINTED IN NIGERIA ISSN 1118-0579

\title{
A COMPARATIVE STUDY OF THE DRYING RATE CONSTANT, DRYING EFFICIENCY, NUTRIENTS AND SENSORY QUALITIES OF DRIED VEGETABLES USING SOLAR DRYER AND OPEN-AIR SUN DRYING METHODS
}

\author{
U. S. ONOJA, J. C. IROEGBU AND J. I. EZE \\ (Received 10 February 2012; Revision Accepted 27 July 2012)
}

\begin{abstract}
The study estimated and compared some drying parameters of bitter leaf (Vernonia amagdalina) and black pepper (Piper guinenses) using solar dryer and open- air sun drying methods. Two hundred grams $(200 \mathrm{~g})$ of each sample were dried under the two different conditions. Their respective weight losses were used to determine the reduction in moisture contents. Drying was assumed to have taken place in the falling- rate period, which enabled the use of only one drying rate constant, K. Graphs of $\ln \left(\mathrm{M}_{0}-\mathrm{M}\right)$ versus time were plotted in each case and used to obtain the drying rate constants, $\mathrm{K}$ for the two drying conditions. The drying rate constants for the solar dryer and open- air sun dried bitter leaf were 0.8 and 0.7 , respectively. Similarly, the values for black pepper were 02 and 0.3 , respectively. Free moisture versus time graphs of both samples were also plotted which showed that the assumption of one falling- rate period is justifiable. The above information would be very critical to farmers as well as to industrial applications because specified levels of moisture content could be linked with a specified time in the process equation. The solar dryer was more efficient but also more expensive and so would be more appropriate to industrial application, whereas open-air sun drying would be more suited for village scale drying of these vegetables. Both the nutritional and sensory qualities of the dried products were enhanced by the process. The adoption of the drying techniques would ensure steady availability of these vegetables all the year round as well as reduce carbon emissions from the conventional drying methods and hence mitigate global warming.
\end{abstract}

KEYWORDS: Solar drying, open- air sun drying, drying rate constant, falling rate, climate change, food ingredients.

\section{INTRODUCTION}

Drying has been generally recognized as the most useful large scale processing technique for prolonging the shelf-life of solid foods including vegetables. Bitterleaf (Vernonia amagdalina) and black pepper (Piper guinenses) are vegetables and belong to the class of agricultural produce often referred to as perishables. Their common feature is that they are abundant during the peak of their respective season but thereafter, become quite scarce. They are well cherished especially in West Africa and particularly, Nigeria where they are widely used in preparations of various soups. They play quite significant role in our diets because they are major sources of essential nutrients, vitamins and micronutrients (Sobukola and Dairo, 2007; Eze and Chibuzor, 2008).

Due to their seasonal nature and high moisture content, there is need therefore, to develop an appropriate technology for their preservation so as to guarantee their availability all the year round. Over the centuries, agricultural produce including vegetables and spices are dried in the open-air sun or in certain parts of the chimneys designated for the purpose in order to dry them
(Scanlin, Renner, Domermuth and Moody, 1997). Whitefield (2000) identified different types of drying techniques including electrical drying, open-air sun drying, firewood/fuelwood drying and solar dryer method. On comparative basis, open-air sun drying ranks first in terms of cost benefit but the poorest when other considerations such as protection against dust, rain and wind, insect infestation, microbial attack and nutrients retention are considered (Muller and Tobin, 1980; Sobukola and Dairo, 2007; Eze and Chibuzor, 2008; Anyanwu and Okonkwo, 2008; Oparaku, 2008).

In order to address the above problems, there is need to adopt advanced drying technologies as practiced in developed countries. However, such technologies are usually cost prohibitive and would not be within the purchasing power of the peasant farmers in the developing countries like Nigeria.

Solar drying is an appropriate technology for a sustainable environment because it has the potential for high product quality, it is inexpensive and most importantly, it is environmental friendly (Ekechukwu, 1989; Markus and Albert, 1996; Whitefield, 2000). A number of complex theoretical models to describe the heat and mass

U. S. Onoja, Department of Home Science, Nutrition \& Dietetics, University of Nigeria, Nsukka, Nigeria.

J. C. Iroegbu, Department of Home Science, Nutrition \& Dietetics, University of Nigeria, Nsukka, Nigeria.

J. I. Eze, National Centre for Energy Research and Development (NCERD), University of Nigeria, Nsukka, Nigeria. 
transfer phenomena in the drying of agricultural products are available (Sobukola and Dairo, 2007). Anyanwu and Okonkwo (2008); Lashsasni, Kouhila, Mahrouz and Jaouhari, 2004; Uretir, Ozilgen and Katnas (1996); Karathanos and Blessiotis (1997); Mwithiga and Olwal (2005); Doymaz (2004 a \& b); Sacilik, Elicin and Unal (2006) have studied the kinetics of solar drying of agricultural products and have come to the conclusion that the process occurs in the falling rate period for most fruits and vegetables. The study was undertaken to quantify the drying rate constants, $\mathrm{K}$ of bitter leaf (Vernonia amygdalina) and black pepper (Piper guinenses) respectively, dried under two conditions: small scale passive solar dryer and open-air sun drying with a view to compare them.

The knowledge of drying rate constant is imperative for accurate prediction of drying rates according to the falling rate model. This information is very important to peasant farmers. It would also be invaluable to industrial applications since specified levels of moisture content could be linked with a specified time in the process design. The objectives of the study were to: (i) determine the moisture content of the samples under two drying conditions: open-air sun drying and solar dryer methods. (ii) determine the drying time and temperatures of the two drying conditions and (iii) determine the drying rate constant, $k$ for both samples at different drying conditions.

\section{Materials and Methods}

Bitter leaf (Vernonia amygdalina) and black pepper (Piper guinenses) used for the study were purchased at Ogige market, Nsukka. Each sample was divided into two equal batches of $200 \mathrm{~g}$. One batch was subjected to openair sun drying while the second batch was charged into a passive solar dryer supplied by the National Centre for Energy Research and Development (NCERD), University of Nigeria, Nsukka. The solar dryer measuring $1025 \mathrm{~mm} \mathrm{x}$ $515 \mathrm{~mm}$ with glass cover uses natural convection principle
(Ekechukwu, 1989; Anyanwu and Okonkwo, 2008). Its North end is $845 \mathrm{~mm}$ high while the south end is $720 \mathrm{~mm}$ high. The glass cover is inclined at an angle of $7^{\circ}$ corresponding to the local latitude (Fig. 1). The sides of the dryer are made of plywood perforated at intervals for effective air flow.

The initial moisture content of the samples was determined using standard techniques (AOAC, 1995). The ambient and drying chamber temperatures during the drying operations were also recorded. Samples were evenly spread during the drying operations to ensure effective drying in consonance with the thin layer model which describe the drying phenomena in a unified manner regardless of the controlling mechanism in the drying of agricultural products (Yaldyz and Ertekyn, 2001; Tongul and Pehlivan, 2004; Sobukola and Dairo, 2007; Dissa, Desmorieux, Bathiobo and Koulidiati, 2011). The initial moisture contents of the samples were $21.6 \%$ and $64.10 \%$ for bitter leaf and black pepper, respectively. They were weighed at intervals of two hours and the moisture content was calculated from the weight loss until a constant weight was obtained when the weighing was then terminated. The samples had to be carried to a sheltered place each time it rained. Samples were kept in desiccators at nights to prevent moisture re-absorption. The drying of each sample was done in triplicate.

\section{Assumptions and data transformation}

In this study, we have assumed that drying occurred in the falling rate period (Lashsasni et al., 2004; Uretir et al., 1996; Karathanos and Blessiotis, 1997). This made it possible to use the falling rate model (eqn.1). In addition, it was also assumed that the drying process was continuous and took place in one falling rate period, hence we employed only one rate constant. Coulson and Richardson (1977) and cited by Anyanwu and Okonkwo (2008) observed that natural convection drying in the falling rate period can be represented by the following model:

$$
\begin{aligned}
& \frac{\mathrm{dM}}{\mathrm{dt}}=\mathrm{e}^{-\mathrm{kt}} \\
& \text { Where } \\
& \mathrm{M}=\text { moisture content at time } \mathrm{t} \\
& \mathrm{t}=\text { time } \\
& \mathrm{K}=\text { drying rate constant }
\end{aligned}
$$

From the above it is obvious that

$d M=e^{-k t} d t$ eqn.

Integrating using appropriate limits we arrive at

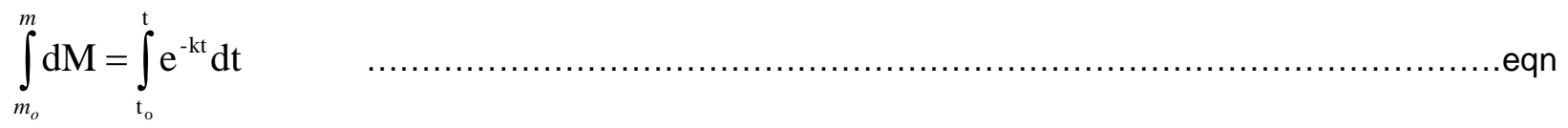

Since the negative power of e shows that $M_{0}>M$ and because $t_{0}=0$

We can write: $\left(M_{0}-M\right)=e^{k t}$ ..eqn.

Where

$M_{0}$ is the initial moisture content of the samples. 
Applying the natural logarithms we arrive at:

$\ln \left(\mathrm{M}_{0}-\mathrm{M}\right)=\mathrm{Kt}$ eqn.

\section{RESULTS AND DISCUSSION}

The results show that while the percentage moisture loss by the open- air and solar dried samples were very close at the second day ( $\mathrm{x} \%$ and $\mathrm{Y} \%$, respectively), the gap widened by the end of the third day ( $\mathrm{X} \%$ and $\mathrm{Y} \%$, respectively). At the end of fourth day (after 48hours), it could be seen that the solar dried samples had lost virtually all its expellable moisture content ( $x \%$ and $y \%$ for $x y$ samples, respectively) whereas the open-air sun dried samples had only lost $\mathrm{x} \%$ and $\mathrm{y} \%$ for the $\mathrm{xy}$ samples, respectively. Moreover, the open-air samples had to be carried into a sheltered place each time it rained. However, this did not entirely prevent its weight from fluctuating as a result of the rainfall which occurred thrice during the period of the study. This is clearly visible from the graphs (Figures 2 and 3). Furthermore, analysis of the plots of $\ln \left(\mathrm{M}_{0}-\mathrm{M}\right)$ against time (Figures 4 and 5) indicates that the rate constant for the solar dried samples are approximately $x$ and $y$ units per day while the open-air sun dried samples are approximately $x$ and $y$, respectively. With these values it is quite possible to link a given level of moisture content with a specified drying time. This could be achieved either graphically or analytically using eqn 5 .

The dry basis free moisture content $(X)$ versus time (t) graphs of both the open-air dried and the solar dried samples are also presented in Figures 3 and 4. Free moisture content was calculated using equations (6) and (7).

$\mathrm{X}=\mathrm{X}^{*} \mathrm{x}_{\mathrm{t}}$

Where $\mathrm{x}^{*}$ is the equilibrium moisture content.

$x_{t}$ is the moisture content corresponding to time, $t$.

Ekechukwu (1999) and cited by Anyanwu and Okonkwo (2008) observed that

$x_{t}$ can be derived from the equation

$\mathrm{x}_{\mathrm{t}}=\frac{\mathrm{W}-\mathrm{W}_{\mathrm{s}}}{\mathrm{W}_{\mathrm{s}}}$

Where $\mathrm{W}=$ weight before drying and

$$
\mathrm{W}_{\mathrm{s}}=\text { weight after drying. }
$$

From the free moisture time graphs it is evident that there are indeed two falling rate periods for each sample. However, the first rate period lasted for less than five hours in both drying techniques, an indication that the original assumption of one rate period is quite justifiable (Anyanwu and Okonkwo, 2008).

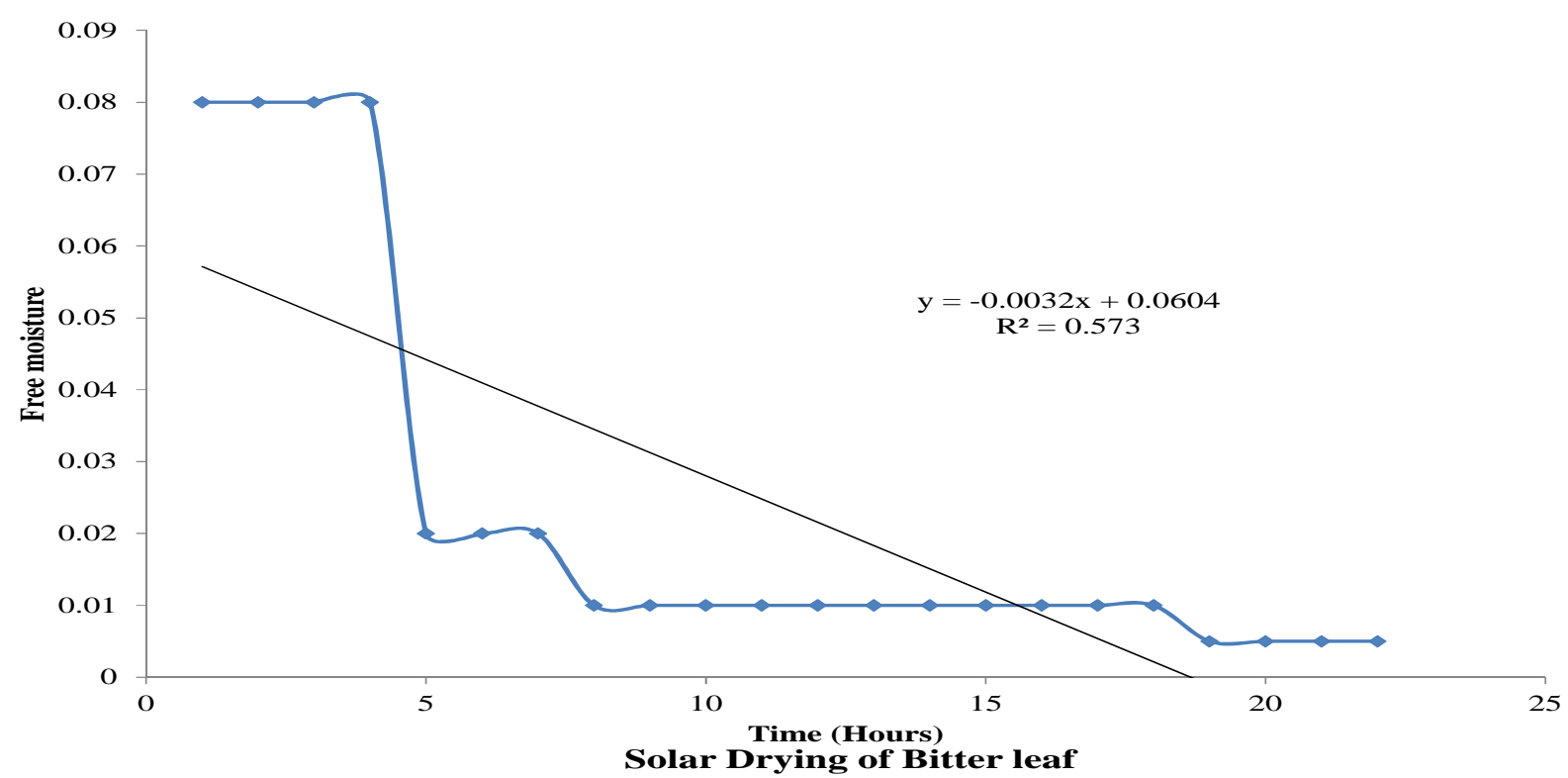




\section{Open Drying Bitter Leaf}

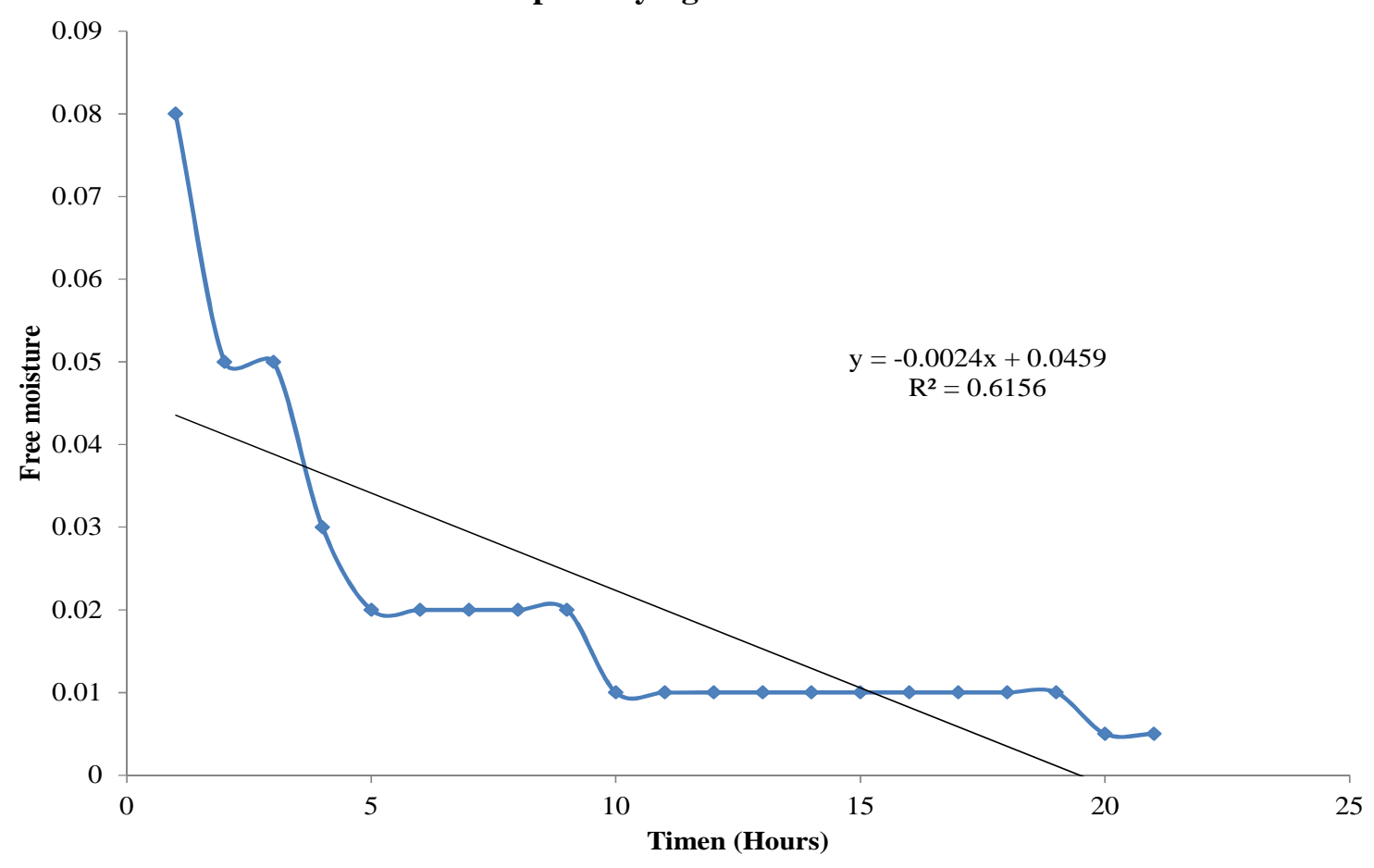

Open - Air Drying for Uziza

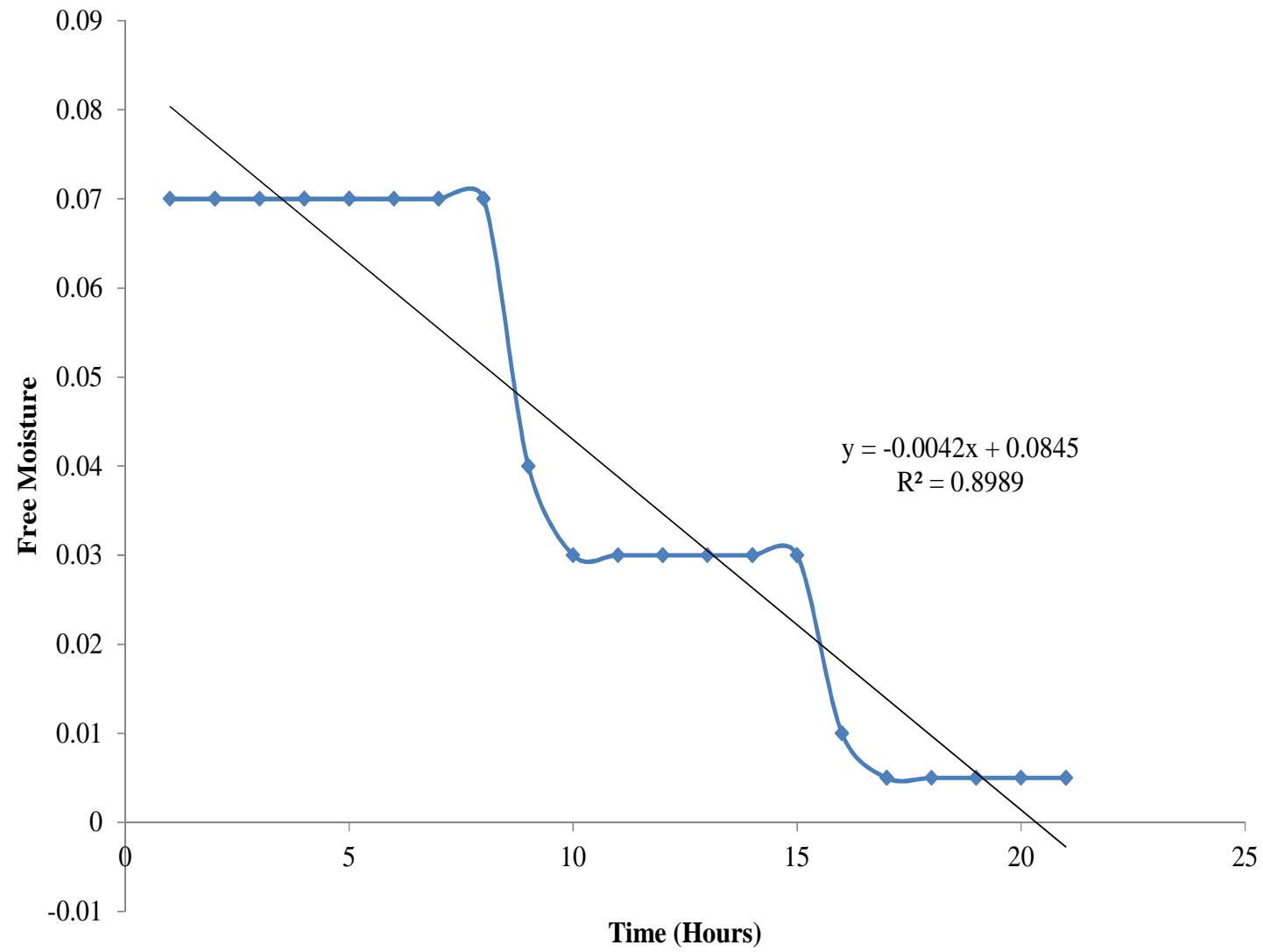



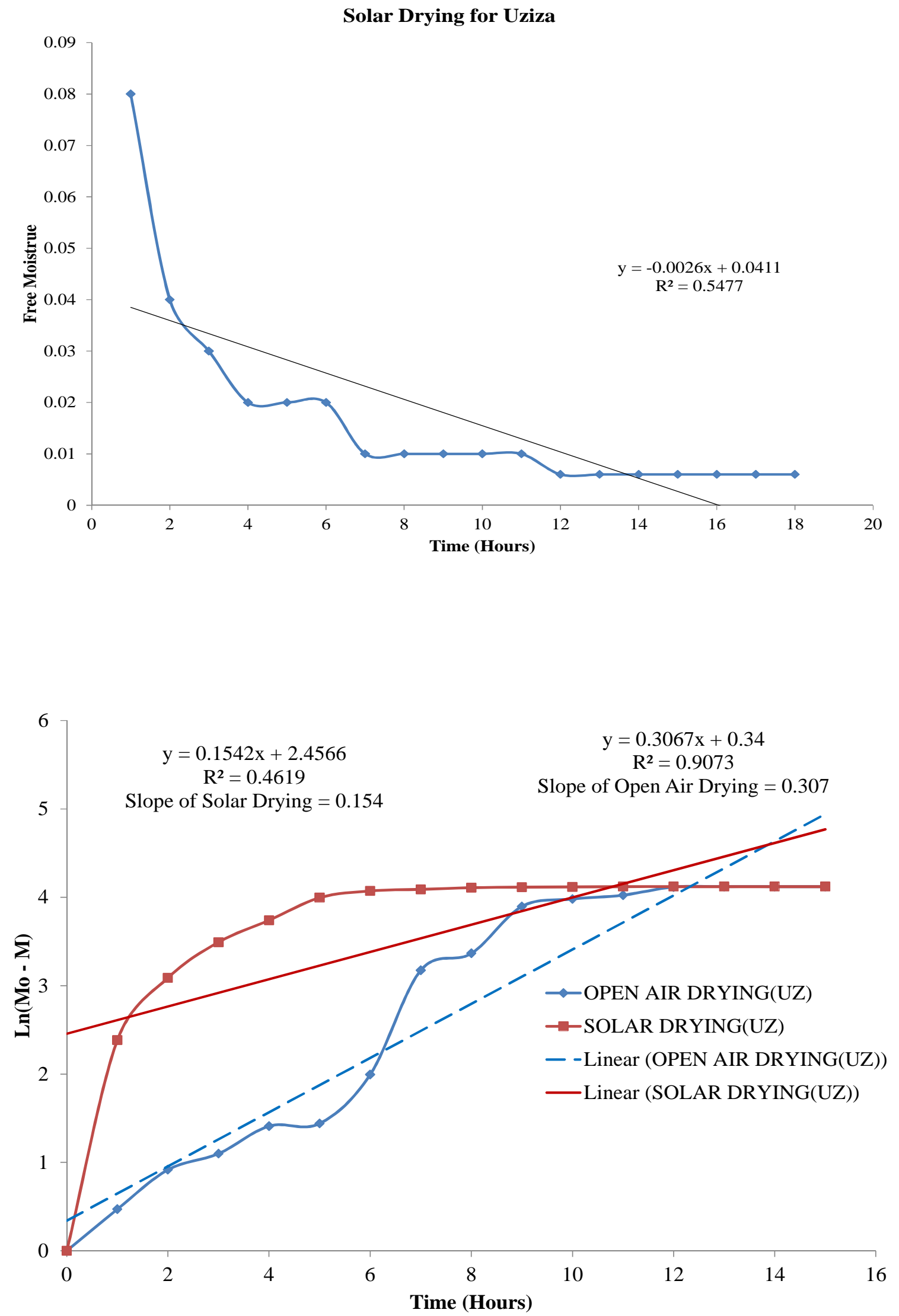


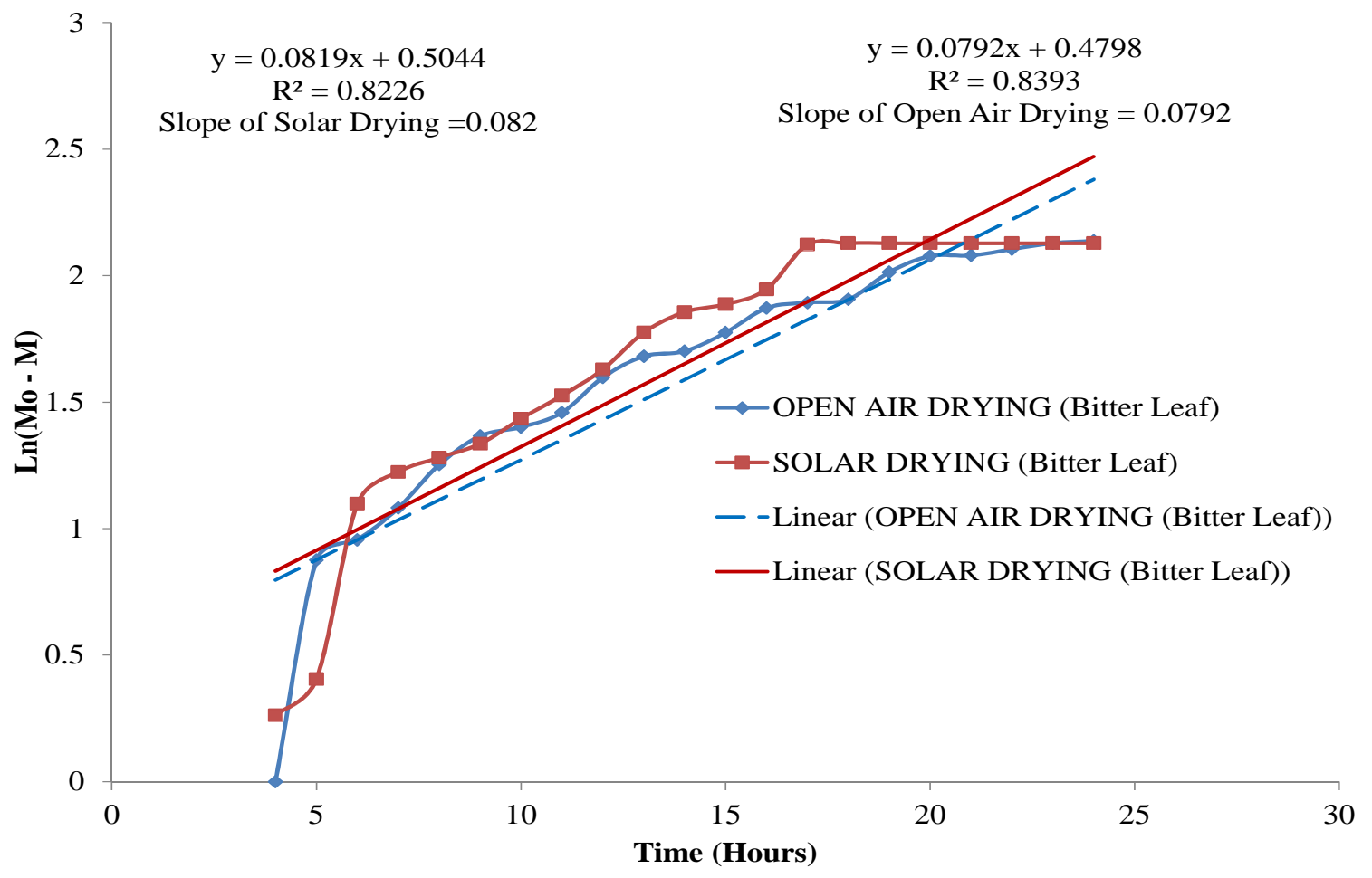

Table 1: Proximate composition of fresh and dry samples

\begin{tabular}{lllll}
\hline Moisture & $\begin{array}{l}\text { Fresh } \\
(\text { mean })\end{array}$ & $\begin{array}{l}\text { Dry } \\
\text { (mean) }\end{array}$ & t-value & p-value \\
\hline Bitter leaf & 71.6 & 13.12 & 237.425 & 0.0000 \\
Uziza seed & 64.10 & 12.49 & 6320.908 & 0.0000 \\
& & & & \\
\hline Protein & $\begin{array}{l}\text { Fresh } \\
\text { (mean) }\end{array}$ & $\begin{array}{l}\text { Dry } \\
\text { (mean) }\end{array}$ & t-value & p-value \\
\hline Bitter leaf & 0.70 & 3.34 & 0.642 & 0.0000 \\
Uziza seed & 0.56 & 2.20 & 533.989 & 0.0000
\end{tabular}

\begin{tabular}{lllll}
\hline Ash & $\begin{array}{l}\text { Fresh } \\
(\text { mean })\end{array}$ & $\begin{array}{l}\text { Dry } \\
(\text { mean })\end{array}$ & t-value & p-value \\
\hline Bitter leaf & 10.5 & 12.91 & 2254.755 & 0.0000 \\
Uziza seed & 11.59 & 12.10 & 429.885 & 0.0000
\end{tabular}

\begin{tabular}{lllll}
\hline Fat & $\begin{array}{l}\text { Fresh } \\
\text { (mean) }\end{array}$ & $\begin{array}{l}\text { Dry } \\
\text { (mean) }\end{array}$ & t-value & p-value \\
\hline Bitter leaf & 0.10 & 0.27 & 836.501 & 0.0000 \\
Uziza seed & 0.20 & 0.12 & 394.368 & 0.0000
\end{tabular}

\begin{tabular}{lllll}
\hline Crude Fibre & $\begin{array}{l}\text { Fresh } \\
\text { (mean) }\end{array}$ & $\begin{array}{l}\text { Dry } \\
\text { (mean) }\end{array}$ & t-value & p-value \\
\hline Bitter leaf & 9.70 & 3.40 & 771.589 & 0.0000
\end{tabular}




$\begin{array}{lllll}\text { Uziza seed } & 12.10 & 3.60 & 25.852 & 0.0000\end{array}$

\begin{tabular}{lllll}
\hline CHO & $\begin{array}{l}\text { Fresh } \\
(\text { mean })\end{array}$ & $\begin{array}{l}\text { Dry } \\
(\text { mean })\end{array}$ & t-value & p-value \\
\hline Bitter leaf & 55.90 & 34.40 & 2633.201 & 0.0000 \\
Uziza seed & 69.50 & 38.10 & 492.908 & 0.0000
\end{tabular}

Table 2: Mineral composition of the different samples

\begin{tabular}{|c|c|c|c|c|}
\hline Ascorbic Acid & $\begin{array}{l}\text { Fresh } \\
\text { (mean) }\end{array}$ & $\begin{array}{l}\text { Dry } \\
\text { (mean) }\end{array}$ & t-value & p-value \\
\hline $\begin{array}{l}\text { Bitter leaf } \\
\text { Uziza seed }\end{array}$ & $\begin{array}{l}31.98 \\
13.84\end{array}$ & $\begin{array}{l}7.20 \\
2.70\end{array}$ & $\begin{array}{l}44.051 \\
7.044\end{array}$ & $\begin{array}{l}0.0000 \\
0.0020\end{array}$ \\
\hline Iron & $\begin{array}{l}\begin{array}{l}\text { Fresh } \\
\text { (mean) }\end{array} \\
\end{array}$ & $\begin{array}{l}\begin{array}{l}\text { Dry } \\
\text { (mean) }\end{array} \\
\end{array}$ & t-value & p-value \\
\hline $\begin{array}{l}\text { Bitter leaf } \\
\text { Uziza seed }\end{array}$ & $\begin{array}{l}4.82 \\
11.4\end{array}$ & $\begin{array}{l}4.15 \\
6.14\end{array}$ & $\begin{array}{l}1.82 \\
47.612\end{array}$ & $\begin{array}{l}0.1410 \\
0.0000\end{array}$ \\
\hline Copper & $\begin{array}{l}\begin{array}{l}\text { Fresh } \\
\text { (mean) }\end{array} \\
\end{array}$ & $\begin{array}{l}\begin{array}{l}\text { Dry } \\
\text { (mean) }\end{array} \\
\end{array}$ & t-value & p-value \\
\hline $\begin{array}{l}\text { Bitter leaf } \\
\text { Uziza seed }\end{array}$ & $\begin{array}{l}0.52 \\
0.89\end{array}$ & $\begin{array}{l}0.01 \\
0.02\end{array}$ & $\begin{array}{l}13.287 \\
12.244\end{array}$ & $\begin{array}{l}0.0000 \\
0.0000\end{array}$ \\
\hline Calcium & $\begin{array}{l}\begin{array}{l}\text { Fresh } \\
\text { (mean) }\end{array} \\
\end{array}$ & $\begin{array}{l}\text { Dry } \\
\text { (mean) }\end{array}$ & t-value & $p$-value \\
\hline $\begin{array}{l}\text { Bitter leaf } \\
\text { Uziza seed }\end{array}$ & $\begin{array}{l}39.01 \\
79.38\end{array}$ & $\begin{array}{l}12.28 \\
17.9\end{array}$ & $\begin{array}{l}20.093 \\
24.869\end{array}$ & $\begin{array}{l}0.0000 \\
0.0000\end{array}$ \\
\hline Zinc & $\begin{array}{l}\begin{array}{l}\text { Fresh } \\
\text { (mean) }\end{array} \\
\end{array}$ & $\begin{array}{l}\text { Dry } \\
\text { (mean) }\end{array}$ & t-value & p-value \\
\hline $\begin{array}{l}\text { Bitter leaf } \\
\text { Uziza seed }\end{array}$ & $\begin{array}{l}0.03 \\
\text { ND }\end{array}$ & $\begin{array}{l}1.15 \\
\text { ND }\end{array}$ & 292.807 & 0.0000 \\
\hline
\end{tabular}

Key:

ND = Not Detected. 
Table 3: Sensory evaluation of the cooked soups

\begin{tabular}{|c|c|c|c|}
\hline Taste & $\begin{array}{l}\text { Treatment } 1 \\
\text { (mean } \pm S D)\end{array}$ & $\begin{array}{l}\text { Treatment } 2 \\
\text { (mean } \pm S D)\end{array}$ & $\begin{array}{l}\text { Control } \\
\text { (mean } \pm S D)\end{array}$ \\
\hline Uz & $5.13 \pm 2.391$ & $6.25 \pm 2.176$ & $6.50 \pm 1.461$ \\
\hline B & $6.13 \pm 1.668$ & $6.81 \pm 1.377$ & $6.44 \pm 2.308$ \\
\hline Texture & $\begin{array}{l}\text { Treatment } 1 \\
\text { (mean } \pm S D)\end{array}$ & $\begin{array}{l}\text { Treatment } 2 \\
\text { (mean } \pm S D)\end{array}$ & $\begin{array}{l}\text { Control } \\
\text { (mean } \pm S D)\end{array}$ \\
\hline Uz & $4.25 \pm 2.082$ & $4.63 \pm 2.277$ & $5.63 \pm 1.147$ \\
\hline B & $5.31 \pm 1.991$ & $6.38 \pm 1.708$ & $6.50 \pm 1.673$ \\
\hline Flavour & $\begin{array}{l}\text { Treatment } 1 \\
\text { (mean } \pm S D)\end{array}$ & $\begin{array}{l}\text { Treatment } 2 \\
\text { (mean } \pm S D)\end{array}$ & $\begin{array}{l}\text { Control } \\
\text { (mean } \pm S D)\end{array}$ \\
\hline Uz & $4.94 \pm 1.806$ & $5.25 \pm 2.176$ & $5.69 \pm 1.401$ \\
\hline B & $5.94 \pm 2.081$ & $6.31 \pm 1.352$ & $6.38 \pm 1.784$ \\
\hline Colour & $\begin{array}{l}\text { Treatment } 1 \\
(\text { mean } \pm S D)\end{array}$ & $\begin{array}{l}\text { Treatment } 2 \\
\text { (mean } \pm S D)\end{array}$ & $\begin{array}{l}\text { Control } \\
\text { (mean } \pm S D)\end{array}$ \\
\hline Uz & $4.50 \pm 1.897$ & $5.19 \pm 2.562$ & $5.63 \pm 1.708$ \\
\hline B & $6.25 \pm 1.693$ & $5.75 \pm 2.145$ & $6.50 \pm 1.713$ \\
\hline General Acceptability & $\begin{array}{l}\text { Treatment } 1 \\
\text { (mean } \pm S D)\end{array}$ & $\begin{array}{l}\text { Treatment } 2 \\
\text { (mean } \pm S D)\end{array}$ & $\begin{array}{l}\text { Control } \\
\text { (mean } \pm S D)\end{array}$ \\
\hline Uz & $4.81 \pm 2.536$ & $5.06 \pm 2.670$ & $6.13 \pm 2.029$ \\
\hline B & $5.88 \pm 2.062^{\mathrm{a}}$ & $6.31 \pm 1.580^{\mathrm{ab}}$ & $7.25 \pm 1.291^{b}$ \\
\hline
\end{tabular}

$$
\mathrm{Uz}=\text { uziza, } \mathrm{B}=\text { bitter leaf. }
$$

\section{CONCLUSION AND RECOMMENDATIONS}

The study revealed the quantification of the drying rate constants, $\mathrm{K}$ and the drying efficiency of bitter leaf (Vernonia amygdalina) and black pepper (Piper guinenses) dried under two conditions: small scale passive solar dryer and open-air sun drying. The freemoisture versus time graphs showed that the drying took place at the falling rate period. Solar dryer was more efficient and has potential to give higher product quality than the open- air sun drying. However, solar dryer would be more costly than the open-air sun drying technique but when quality and safety are considered, the former should be better in the drying of vegetables. The process if adopted would ensure steady availability of these vegetables all the year round.

\section{ACKNOWLEDGEMENTS}

The researchers are deeply grateful for both the staff and management of National Centre for Energy Research and Development (NCERD), University of Nigeria, Nsukka for allowing us to use the Solar Dryer equipment for the research.

\section{REFERENCES}

Anyanwu, C. N and Okonkwo, W. I., 2008. Experimental determination of the drying rate of chilly yellow pepper (Capsicum anuum). Nigerian Journal of Solar Energy (19-1): 18- 24.

Chua, K. J., Mujumdar, A. S and Chou, S. K., 2003. Intermittent drying of bioproducts - an overview. Bioresource Technology (90): 285-295.

Dissa, A. O., Desmorieux, H., Bathiebo, J and Koulidiati, J., 2011. A comparative study of direct and indirect solar drying of mango. Global Journal of Pure and Applied Sciences. 17, (3): 273- 294.

Doymaz, I., 2004a. Drying kinetics of white mulberry. Journal of Food Engineering (74): 341-346.

Doymaz, I., 2004b. Pretreatment effect on sun drying of mulberry fruit (Morusalba L). Journal of Food Engineering 65, (2): 205-205. 
Ekechukwu, O. V., 1989. Performances of a large integral type passive solar energy dryer for rural application. National Centre of Energy Research and Development Journal, (1): 173- 176.

Ekechukwu, O. V., 1999. Review of solar energy drying systems: An overview of drying principles and theory, Energy conversion \& management (40): 593.

Eze, J. I and Chibuzor, E. E., 2008. Evaluation of the drying efficiency of solar cabinet dryer using okro and tomato. Nigerian Journal of Solar Energy (191): 25- 33.

Karathanos, V. T and Belessiotis, V. G., 1997. Sun and artificial air drying kinetics of some agricultural products. Journal of Food Engineering (31): 3546.

Lashsasni, S., Kouhila, M., Mahrouz, M and Jaouhari, J. T., 2004. Drying kinetics of prickly pear fruit (Opuntia ficus indica). Journal of Food Engineering (61): 173179.

Markus, $\mathrm{H}$ and Albert, E., Solar Tunnel dryers for agriculture. Journal for energy research (2): 2627.

Muller, H. G and Tobin, G., Nutritional and Food Processing. The AVI. Publication Co. Inc. Westport Connecticut. pp 27

Mwithiga, G and Olwal, J. O., 2005. The drying kinetics of kale (Brassica oleracea) in a convective hot air dryer. Journal of Food Engineering (71): 373-378.

Oparaku, N. F., "Drying Characteristics of solar \& opensun dried Clarias lazera fish". Journal of Science \& Technology Research 12, 42-47.

Sacilik, K., Elicin, A. K and Unal, G., 2006. Drying kinetics of Uryani plum in a convective hot air dryer. Journal of Food Engineering (76): 362-388.

Scanlin, D., Renner, M., Domermuth, D and Moody, H., 1997. The design, construction and use of an indirect through-pass solar food dryer. Home power (57): 62-72.

Tongrul, I. T and Pehlivan, D., 2004. Modeling of thin layer drying kinetics of some fruits uder open-air sun drying process. Journal of Food Engineering (65): 413-425.

Uretir, G., Ozilgen, M and Katnas, S., 1996. Effects of velocity and temperature of air on the drying rate constant of apple cubes. Journal of Food Engineering (30): 339- 350 .

Whitefield, D., 1996. Solar dryer systems and the internet: Important resources to improve food preparation;
Conf. paper: Int'I Conf. on solar cooking, Kimberly, South Africa.

Yaldiz, O and Ertekyn, C., 2001. Thin layer solar drying of some different vegetables. Drying Technology 19, (3 \&4): 583-597. 